\title{
Damascus in Dahlem
}

\section{Art And Nature In Burle Marx' Tropical Landscape Design'}

\author{
Luiz Fernando Dias Duarte
}

One of the main features of Roberto Burle Marx's [1909-1994] official biography is the idea that he discovered the aesthetic qualities of tropical flora that came to characterize his famous new approach to landscape design during a juvenile visit to Berlin-Dahlem Botanical Gardens, in the 1920s. This topic is repeated in all texts about his life, even the shortest ones, echoing a point he eventually expressed himself - although not as preeminently as his interviewers and biographers came to do.

Having been born and brought up in Brazilian metropolises, he is supposed not to have had a previous contact with tropical spontaneous richness, thanks to the Europeanized taste that prevailed in their gardens and urban landscape at the time. As for any young member of the local elites with a disposition towards an artistic career, his family trip to Europe was an essential condition for establishing close contact with the avant-garde tendencies of early 2oth century. It was also usual for less fortunate prospective Brazilian artists to depend on government or on a private patron to allow for the "European trip" that would open the paths of a creative career. Ever since the 19th century, that pattern of contact with "civilization" had entailed the emergence of different trends of "nativist" renderings of metropolitan taste. In such a context, the peculiar aspect of Burle Marx' European début seems to be the "discovery" of tropical nature and not only that of the formal, "universal" language of high culture. The processes that led to this game of mirrors are the aim of my discussion, addressing the particular version of the tension

\footnotetext{
1 This text was first presented at the Fifth International and Interdisciplinary Alexander von
} Humboldt (Travels Between Europe and the Americas). Freie Universität, Berlin, 2009 
between the ideas of art and nature that emerges in a Latin American artistic career in the $20^{\text {th }}$ century.

A passage from the entry for Burle Marx' name [henceforth referred here as BM] in Wikipedia is quite explicit about his European conversion: "[his] first landscaping inspirations came while studying painting in Germany, where he often visited the Dahlem Botanical Gardens and first learned about Brazil's native flora. Upon returning to Brazil in 1930, he began collecting plants in and around his home" (Wikipedia, 2009) ${ }^{2}$. In fact, the impact of the discovery of luxuriant Brazilian plants collected by Eichler (cf. Tabacow, 1904: 221) and organized in the hothouses of the Botanical Gardens in Berlin was explicitly acknowledged by BM: “The Brazilian plants I had not seen in Rio de Janeiro, I came to find in the greenhouses of Dahlem, Berlin. It was thanks to these visits that I experienced the desire to know our flora" (apud Tabacow, 2004: 15). The same theme appears in another interview: "When I am asked where did I perceive the aesthetic qualities of the autochthonous elements of Brazilian flora, from where did I obtain the will to build an entirely new order of plastic composition with the native plants of this land, I can only frankly answer that it happened when I was studying painting in the greenhouse of Brazilian tropical plants in Berlin Botanical Garden! It was there that I realized the strength of the pristine nature of the tropics, that I had there, in my hands, as raw matter ready to serve to my own artistic project - even though it was still insufficiently defined" (apud Leenhardt, 2006: 67).

This is however not an isolated reference. His own description of the whole process of conversion to the cult of plants and gardens is considerably more complex. It begins in São Paulo, where he was born and lived up to the age of four. These early memories include his mother's rose-garden and the greenhouse with variegated species of the Caladium and Begonia genera, so typical of her tropical Recife whence they probably came. They include also the emotion of the first radish taken directly from the soil, cultivated by the family's Hungarian born governess. At the age of seven, already living in Rio de Janeiro, in a large villa near Copacabana beach, his first collection of plants began to grow, including a specimen of Alocasia cuprea, whose beauty entirely astonished him. His gardening interests inspired his father

2 See also, for example, Cals, 1995: 128; Siqueira, 2001: 15; Leenhardt, 2006: 9, 67, 72, 75; Vieira, 2007: 188; Itaú Cultural, 2009. 
to subscribe to several specialized magazines, including the German Garten Schoenheit. These vegetal reminiscences are inextricable from the family's immersion in art. His mother played the piano and sang - exposing her children to an early and intense musical experience.

In 1928 the family moved to Berlin and BM plunged into the burgeoning artistic life of the Weimar republic. Besides the impact of tropical flora in Dahlem, inspiration flowed from art expositions; musical, theatrical and ballet novelties. In his own description of those intense years (in fact, just one and a half years), the discovery of Cézanne, Matisse, Braque, Klee, Van Gogh and Picasso were tantamount to a conversion, just as much as that unleashed by Dahlem's hothouses. The road to Damascus was certainly broader ...

BM came to be a monument of Brazilian official identity, as the inventor of a new style of urban design, of landscape and gardening art. His manifold genius inspired an early public recognition as an icon of national creativity in the challenging period between the Revolution of 1930 and the military coup of 1964. His family background and his personal career had pushed him into a complex, hybrid and challenging identity: a Brazilian mother (of French descent) and a German father (of Jewish descent); the son of cultivated parents, with a high social standing, and an easy dialogue with popular life and art. As a connoisseur with a successful professional career he never lost his amateurish universal ambition; as an overt homosexual, he attended the most prestigious levels of government and elite circles; as a devoted enthusiast of Brazilian society and nature, he maintained an entirely cosmopolitan life style and won international recognition.

He was thus an easy target for national reflexivity concerning the Western historical tension between civilization and nature, in the particular Latin-American guise of a clash between Europe and the Tropics. Having been born in São Paulo and brought up in Rio de Janeiro, living in prestigious villas in the Avenida Paulista and in Copacabana (Leme), it is relatively easy to suppose that he had not had an intense contact with tropical spontaneous richness, thanks to the Europeanized taste of gardens and urban landscape in Brazilian metropolises. Yet he had cultivated in the vast gardens of the Copacabana villa at least his own Alocasia cuprea - an Aracea quite expressive of tropical exuberance, even if Asiatic at that. He is reported as having brought all sorts of wild plants to the family garden, under the approving eye of his mother (Oliveira, 2007: 22). Even nowadays, the slopes of the hill 
behind Leme (in spite of encroaching urban growth ) present a dense, deep green example of the Atlantic forest, typical of Brazil's Eastern coast.

The tension between European civilization and tropical natural conditions had always been ritualized by the voyages between the Old World and the New one - as an inevitable corollary of the colonization process. After Independence, this pattern assumed new shapes, depending less on Portuguese mediation and varying according to the new social and economic processes that emphasized a more cosmopolitan and "modern" attitude. The fact that Brazil continued to be ruled by a royal family deeply connected to European courts added a particular blend to these exchanges - affecting most notably the aristocratic strata ${ }^{3}$. Regular artistic and scientific exchanges had begun with the transfer of the Portuguese Court to Rio de Janeiro in 1808. French art had been particularly favored since the so called French Artistic Mission ${ }^{4}$ and remained a main source of influence during the whole of the $19^{\text {th }}$ and the first half of the $20^{\text {th }}$ century - with many personal long-term adaptations of French artists to Brazilian life. This had been the case for such influential artists as the architect A. H. Grandjean de Montigny, the painter N.-A. Taunay and his family (cf. Schwartz, 2008), the photographer Victor Frond (cf. Segala, 2006) and the landscape architect A. F. Glaziou (cf. Terra, 1993).

In the opposite direction, a constant flow of rich young Brazilians to Europe became almost a prerequisite for successful careers in the liberal professions, in science and in the arts. In the latter area, it became usual for prospective Brazilian artists to take profit from their European experience to launch their creative careers, exploring the different possibilities of "nativist" versions of metropolitan taste 5 - mainly after the diffusion of romanticism and its emphasis on historical and "natural" roots.

3 Two good examples of the exchanges at that level are those of the international careers of Luísa M. de Barros Portugal, Viscountess of Pedras Brancas and Countess of Barral (cf. Del Priore, 2008), and Eufrásia Teixeira Leite, grand-daughter of the Barons of Itambé and Campo Belo (cf. Falci \& Melo, 2002).

4 In 1816 arrived in Rio de Janeiro a group of French artists who had to flee from their country after the defeat of Napoleon. They were engaged by King João VI, through the indirect influence of Alexander Von Humboldt. They would play an essential role in the development of Brazilian art. The group was initially led by Joachim Lebreton and some of its members came to be the founders of the Imperial Academy of Arts.

5 From the cases of the eminent painters M. Araújo de Porto-alegre, Pedro Américo and Victor Meirelles or the composer Carlos Gomes to those of the composer Heitor Villa-Lobos or the painter Candido Portinari, already in the 2oth century. For the personal patronizing action of the Emperor Pedro II in the realm of arts during the 19th century, see Schwarcz, 1998. 
The Brazilian case is, of course, just one instance of a general feature of American cultural life - entirely dependent, from its inception, on European sources: an ideological condition that had emerged itself as a mirror image of European attraction for the New World it had invented ${ }^{6}$. The specific mystique of the American continent cannot be confounded with the imaginary focus upon the Tropics, but - in the case of Brazil - the blending was inevitable: a "tropical America", with its profusion of luxuriant forests, exuberant rivers and sandy beaches, teeming with parrots, pineapples, palm trees and caimans.

A pioneer in the blending of cosmopolitan tastes and tropical scenery was J.-B. Debret, nephew and disciple of J.-L. David. Debret was the official artist of Independence and the First Empire in Brazil. In his watercolors, we can still admire the way he recast French late neo-classical, Empire style, in the imagery of the new nation, including the design of the flag and the royal insignia - full of references to the local natural world (which meant the inclusion of the Amerindians, at the time) (cf. Bandeira, 1999). But the trend towards what was thought of as a kind of hybridization continued - of course - well into the $20^{\text {th }}$ century. It was only after World War II and the establishment of contemporary conditions of "globalization" that such exchanges came to be considered as a regular dimension of all cultural life, disentangled from nationalist and nativist considerations.

The impulse towards hybridization grew intensely under the influence of romantic cosmology and imagery (cf. Gusdorf, 1985; Taylor, 1989; Duarte, 2007). The emphasis on "nature" had entailed a series of crucial transformations in European high culture since the $18^{\text {th }}$ century. Four, at least, have to be mentioned more specifically, since their influence can be traced as far ahead as BM's life project. First, there was an inner natural quality of the self that could be called "sensibility", "creativity" or "authenticity," that imposed new rules for life projects and artistic careers?. In the second place, there was a new concern with gardens that had assumed in England the shape of the

6 The famous voyage of Alexander Von Humboldt serves usually as a privileged example of this attraction - and of its extraordinary results and influence. A recent work has demonstrated the intensity of the interest Goethe himself took on Brazil, from a distance, inspired by the work of Carl Friedrich Philipp von Martius - the author of the Flora Brasiliensis (cf. Schneider, 2007). Charles Darwin's circumnavigation of South America has been another frequent focus of this theme.

7 The process that led to the development of this new self came to be known as the Bildung (cf. Bruford, 1975 and Taylor, 1989), one of the bases of modern Romantic personhood. 
"landscape gardening", a rejection of baroque conventions in favor of a "natural" lay-out, absence of walls and a prevalence of dense masses of greenery. This was the landscape appropriate for the sensible souls in search of intimacy with nature. In the third place, there was an emphasis on the authenticity of popular national roots, with a growing concern with national origins and history ${ }^{8}$. And - last but not least - the reintroduction of the theme of wholeness, that had seemed banned from civilized excogitations since the Enlightenment. Wholeness was expected to become embodied in a personality, in a work of art, in a nation, in a landscape, in a collective project - always enlivened by natural conditions and authentic dispositions.

These new cosmological grounds imposed an intense investment in the dialogues and compromises between "nature" and "civilization", always ambivalent and contradictory. The challenge was as present in Europe as in the Americas, but tropical conditions seemed to enhance its dramatic qualities to an almost hysterical level. It is not possible to expatiate here about the way the four romantic ideals could materialize in $19^{\text {th }}$ century Brazil. Just a brief note on their relationship to gardens is necessary, so as to provide a better understanding of the myth of the conversion in Dahlem.

Until the beginning of the $19^{\text {th }}$ century, Brazilian gardening experience was very restricted, although monasteries and manors did have enclosed gardens in the medieval tradition, combining utilitarian and aesthetic concerns. The first public garden, the Passeio Público of Rio de Janeiro, was opened in 1783 , designed in the baroque taste still prevalent at the time in Portugal. A major change emerged in the middle of the century as the Emperor decided to invite the French botanist Auguste F. M. Glaziou, to be engaged as the Director of Parks and Gardens of the Crown [1858]. Glaziou had been trained in the urban renewal of Paris, under the direction of Jean-Charles A. Alphand, who favored landscape gardening. Under the direction of Glaziou almost all of the important public and royal gardens were renewed in the romantic taste (including the old Passeio Público), establishing a new trend for the gardens of the imperial elites - full of shady shelters, green groves, lakes and meandering paths (cf. Terra, 1993; Leenhardt, 2006: 13; Dean, 1991). As in Europe, the alternative styles known as "picturesque", "gardenesque", and

8 A phenomenon analyzed by Duarte as the cult of a "national nature" (2005). S. Schama wrote most inspiringly on the theme of "national" forests (1995). 
"wild" came to influence the smaller gardens, surrounding the urban cottages of the bourgeoisie.

The situation at the end of the $19^{\text {th }}$ century was - as for others arts characterized by an eclectic mixture of all these traditions. In fact, the very gardens by Glaziou had won such general applause because of their hybrid quality, incorporating many native species to the main scheme of landscape gardens (cf. Vieira, 2007: 180). A peculiar mixture of native and exotic plants obeyed the logic of European patterns and designs, either in the grand direction of landscape gardens or in that of private middle class flower-bed gardens. In both of them an emphasis in individual specimens, remarkable for their flowers, fruits or perfume, prevailed; be it trees or shrubs. Few public gardens had retained by then the spirit of landscape gardening, with its all green palette and its alluring perspectives. In Rio de Janeiro, the gardens of Campo de Santana, Quinta da Boa Vista and Passeio Público, in spite of uninspired partial renewals and the permanently mediocre upkeep, are still lively examples of that style. The Tijuca Forest, a public park in the same city, retains as well a certain flavor of the imperial taste.

Those were the gardens that BM must have visited and known both in São Paulo and Rio de Janeiro up to his European début. It was certain that they did not mirror the exuberance of tropical forests, but it was also certain that they were not entirely exogenous and "rootless" (so to say). The characteristics that would come to oppose most clearly belle-époque Brazilian gardens to those that BM began to propose in the 1930 sere the preference for color and shape through foliage and not flowers (Blacker, 2000; Elliot, 2003) and the use of masses or groves of vegetation as against individual or bed planting.

What BM discovered in Dahlem was thus not exactly the richness and beauty of tropical flora, but a new context for it, a new sense of its aesthetic potential - and this was not different from his other discoveries in the realms of painting and music. He already knew all of Richard Wagner's Leitmotive by heart and was becoming a specialist in Lieder singing - just as he was acquainted with current reproductions of European painting up to the Impressionists. But then there were Cézanne and Strawinsky, Picasso and Debussy: a new sense of "association" and "composition", two key words to his personal view of his own artistic evolution.

As for any young Brazilian artist, the trip to Europe meant entering into direct contact with the sources of Western civilization and art - and an 
introduction to avant-garde circles. What came to be peculiar in the myth of BM's European début seems, at first glance, to be the "discovery" of nature in Europe and not that of culture, civilization or art. In fact, many biographies of the artists exposed to the experience of the European trip make explicit the fact that what was sigbnificant about the experience was not exactly the exposure to the new forms of high culture expression but rather the discovery of the inner "nature" they carried within them from their pristine origins, the forms of sensibility that had condensed in contact with their original "natural" environment and would henceforth be the guarantee and gauge of a prized "authenticity". Yet to be in Europe, exposed to the cream of Western civilization, to the acme of artistic expression, was an essential condition for conversion, the release of the inner forces that pulsed there, imperceptible, the touch of quicksilver that would catalyze the gold hidden amid brutish pebbles ${ }^{10}$.

This is the general myth. BM's version is peculiar because of the nature of the "nature" involved: the specimens of Brazilian flora had already been carried to an European Botanical Garden, had been organized there according to Adolph Engler's new phytogeographical conception ${ }^{11}$ and presented themselves thus in an entirely new frame. The sensory references of the tropical world that BM carried in his juvenile memories were rearranged in a new "composition", pre-ordained, so to say, as elements for further "associations". The raw material for other kinds of arts could not be organized in that manner. The immediacy and concreteness of the references to original nature discovered in Dahlem could thus express in the most adequate way the spirit of the encompassing myth. With an irresistible intensity it rendered palpable what was essential for the process of conversion of all the virtuosi in Western modern culture: the discovery of inner original "nature" and the prospect of reaching the Holy Grail of "total" expression.

A few further years of training ensued in Rio de Janeiro, in contact with important thinkers and artists in the National Beaux-Arts School and

\footnotetext{
9 The cases of Villa-Lobos, as studied in Guérios, 2003, and Candido Portinari, as studied in Reinheimer, 2008, are outstanding examples of this social effect, in spite of their sharply different personalities.

10 "I am very Brazilian. That is something I discovered in Berlin, in 1928" (BM apud Siqueira, 2001: 117).

11 Adolph Engler, a former Director of Dahlem Botanical Garden, is considered as the father of phytogeography. He had an interest and was engaged in the creation of ecological parks (Leenhardt, 2006: 10). It is very probable that his presentation of natural biogeographical units in Dahlem had its roots in Alexander von Humboldt's concept of the character of places and the physiognomy of plants.
} 
the Art Institute of the University of the Distrito Federal ${ }^{12}$. Some biographers underline the importance of two books in these formative years. Both are considered as "classics" of the modern interpretation of the nation: Os Sertões [Rebellion in the Backlands, 1902], by Euclydes da Cunha (Leenhardt, 2006: 10; Vieira, 2007: 189), and Casa Grande e Senzala [The Masters and the Slaves, 1933], by Gilberto Freyre. They stress the importance of native "roots", the deep embeddedness of national identity in its natural milieu and its cultural origins.

BM first won public acclaim in 1936, with his project for the gardens of the Ministério da Educação building, in Rio de Janeiro - a landmark of modernist architecture in Brazil. He was later involved with the important group of architects and artists that gathered around Lúcio Costa (under the general influence of Le Corbusier) and who came to be internationally known because of their participation in the project of Brasilia in the $1950 \mathrm{~s}^{13}$.

The success of his activities in landscape architecture led BM to increasing contact and exchange with botanists, botanical illustrators and photographers. In fact, he was acknowledged as a colleague by the botanical Brazilian community and participated in innumerable scientific expeditions to the interior of Brazil. This cooperation began during his first public service in Recife and reached its peak probably with the ambitious project of the Parque do Flamengo, in Rio de Janeiro.

The biographers insist, certainly with good reason, on the importance of the intellectual and artistic circles that surrounded BM all through his life (Cals, 1995: 129; Leenhardt, 2006: 15; e. g.). In fact he was a skilled social entertainer and cultivated these coteries with minute intensity, mostly after the opening - in 1949 - of his personal master-piece, the estate of Sítio da Bica de Santo Antonio, on the outskirsts of Rio de Janeiro. There, he held day long receptions emulated Renaissance parties, with the host offering his own music, food, poetry declamation and table decoration, in a tropical Gesamtkunstwerk in an extraordinary architectural and garden setting.

The ideal of the romantic wholeness was explicitly cultivated. In an

\footnotetext{
12 He was a student of the writer and music researcher Mário de Andrade and of the painter Candido Portinari. Although Gilberto Freyre (BM's reference about the history of gardens in Brazil) lectured at the Universidade do Distrito Federal, their mutual acquaintance seems to have taken place elsewhere. 13 Besides Lúcio Costa and Le Corbusier, the group included architects and artists such as Gregori Warchavchik, Jorge Machado Moreira, Affonso Reidy, Oscar Niemeyer, and Candido Portinari.
} 
interview, BM said that it was one's duty "not to restrict oneself to a single thing" (apud Oliveira, 2007: 24). In the beloved German he had learned from his father, the word Vielseitigkeit (manysidedness) had been a motto for the Bildungsbürgertum style his family had proudly affected. These qualities of BM's private life may be considered as indiscernible from certain qualities of his public, artistic activity. "Association" and "composition" were key concepts in his worldview. These were qualities he declares to have perceived in Dahlem, in the observation of groups of plants organized according to their original habitats, leading to comparisons between homologous ecosystems rather than between individual species or genera - the result of the famous work of Engler ${ }^{14}$. The "tropical world" became a rational entity as much a domain of sensory feeling. "Association" is closely related to the idea of "composition": it is through a process of associative chains permeating the sensory and the intelligible that a "composition" arises, be it in music, in painting or in landscape design. BM describes plants as a "vocabulary" out of which the language of gardens can take shape $\mathrm{e}^{15}$.

His practice of direct observation of phytogeographical habitats throughout Brazil implied this interest in the local sum of associations that offered to the observer a sense of "wholeness" similar to a work of art and that could inspire artistic creativity in the production of a man-made simile - a "composition". The trips around Brazil, the botanical collecting and the observation of many "natural" landscapes led him to develop a peculiar taste for certain formations that continually reappear in his projects: the buriti palm [Mauritia flexuosa] groves, the "restingas", the "campos rupestres" and the "campos de altitude"16. It is interesting that these systems are not the most typical examples of tropical exuberance. They tend, rather, to be more sparse, to concentrate on fewer species, to present larger communities of the same associations and to allow for wider vistas and for a "cleaner" visual decoding. BM explicitly expected that the richness and variety of the flora of the

\footnotetext{
14 The category "association" and its relation to Engler's work is present in BM's texts published in Oliveira, 2007: 25 and in Leenhardt, 2006: 55.

15 The references to "composition" can be found in Leenhardt, 2006: 48, 50.

16 According to the botanist Ivone Manzali de Sá (personal communication), the names for these "landscapes" do not have equivalents in the English language: "restinga" occurs in coastal plains; "campos rupestres" are dry, quartzite fields within the area of the cerrado (savannah like formations of Central Brazil) and "campos de altitude" are also drier, stony areas on top of the huge granitic boulders that abound in certain areas of the Atlantic forest.
} 
inter-tropical belt could be translated into gardens conceived as "microclimates" (BM apud Leenhardt, 2006: 57) - but this involved a selection of the landscapes that could be transmuted in human-centered, aesthetically organized, spaces. In a similar sense, BM was interested in transitional formations, between different phytogeographical areas, where the possibilities of new compositions were naturally offered. New compositions were also a characteristic of landscapes affected by human destruction where vegetation was beginning to return - establishing new, mutant, patterns (Siqueira, 2001:8).

An important aspect of the attention BM paid to "natural" wholeness as conducive to "total works of art" was this capacity of "mutation", change, implicit in plant associations - a quality that had to be taken into consideration in landscape design (BM apud Leenhardt, 2006: 52). Again, the romantic spirit, with its emphasis on flux, on the dynamic qualities of organic world, seems to hover above him: "The garden is related to all these functions that exist in nature as an organic whole" (BM apud Tabacow, 2004: 20) or "the main difference $[. .$.$] between the bi-dimensional painter and tridimensional$ landscape designer is that the plant - the raw material - is not static" (BM apud Siqueira, 2001: 15).

Wholeness in the artistic production of BM could also mean a search for synesthesia: "A garden is made out of light and sounds" (GM apud Pinheiro \& Modesto, 2008: 130). This dimension of the "total work of art" is obviously explicit in his own sense of an expressive life: his manifold creative activities and his continuous "associative" action ${ }^{17}$. But it is also present in his landscape compositions: associations among plants themselves; associations between plants and mineral elements (water and stone); associations between "natural" components and human-made pieces (statues, quarried stones recovered from urban ruins); associations between gardened areas and surrounding forest. And certainly also his unusual disposition to design gardens that would be experienced both from within (from a "normal" human perspective) and from above, à vol-d'oiseau, in the manner of a huge carpet displayed above the ground - as specialists have frequently emphasized ${ }^{18}$.

17 BM spoke approvingly of Baudelaire's "theory of correspondences", in the search for a "global sensorial experience" (Leenhardt, 2006: 33).

18 The multifaceted quality of BM's work was the axis of his first international art book, published by Pietro Maria Bardi (with photographs by Marcel Gautherot): The Tropical Gardens of Burle Marx (1964; 
The attention to the phenomenological, sensory, qualities of each species and the search for an appropriate locus for its development within the garden can also be considered as a dimension of wholeness. Plants present to human experience in Western culture an interesting challenge: they materialize their "individual" condition both as specimens and as species ${ }^{19}$. This is probably the reason why the reference to a "plant" in the following excerpt of BM can be understood in both senses: "A plant is shape, color, texture, and smell; a living being with needs and preferences, with its own personality. [...] One may think of a plant as a brush stroke or as a stitch in a piece of embroidery, but one cannot forget that it is an individual. One must always try - as much as possible - to make it look like itself" (apud Siqueira, 2001: 31). The general Western cult of the individual presents itself here in the guise of what G. Simmel called the "qualitative individualism", the romantic emphasis upon the wholeness of individual ontology (a "personality"). In fact the passage is even more illuminating: it addresses the possible tension between the wholeness of the work of art, where the plant is a "brush stroke", and the wholeness of each living constitutive element of the garden.

The personal experience of the devastation of the environment in Brazil led BM to a growing investment in the public preservation of nature (Robério Dias apud Lorenzi \& Mello Filho, 2001: 7; Siqueira, 2001: 7), with many proposals for ecological parks. He did eventually declare that the creation of gardens could be considered as a counterpoint to the destruction of original landscapes: these artificial "micro-climates" should be conceived and experienced as refuges redolent of pristine nature (BM apud Pinheiro \& Modesto, 2008: 163). A new compromise between nature and civilization.

The international recognition of BM's work led to a growing literature about the artist and the characteristics of his contribution to landscape architecture. Viewed from abroad BM becomes more typically "modernist" than he is commonly considered in Brazil. One author speaks of Brazilian modernism as a "modernism with gardens" (Michel Racine, apud Leenhardt, 2006: 114). Another considers his work as a translation of modernism into landscape (Leenhardt, 2006: 89). A recent exposition in the Paço da Cidade (Rio de

New York : Rheinholt). On Gautherot, who worked closely with BM for decades, see Angotti-Salgueiro, 2007.

19 C. Lévi-Strauss dedicated a whole chapter of his book on the "savage mind" to a broad version of this challenging topic: "The individual as a species" (1970). 
Janeiro ${ }^{20}$ tried to convey the broad scope of BM's artistic activity, against common sense reduction of his profile as that of a garden designer. But the characteristics of his peculiar "modernism" still require careful development.

The myth of the conversion in Dahlem has a curious counterpart in a recent and - as far as I know - isolated interpretation of BM's originality, as compared to the fellow modernist landscape architects of his generation. Arnaud Morières considers that the advantage BM had above the European colleagues was that of an "invention on a blank page". European modernist landscape architects would be too much laden with their centuries old tradition, and had difficulty in abandoning some of the canons of "classical" design (apud Leenhardt, 2006: 91), while a Brazilian could operate more freely in a desert of cultural experience (and - of course - a paradise of natural stimuli). Such a perspective seems quite ironic in the light of the complex cultural game of mirrors that led BM to Damascus and beyond. Dahlem's greenhouses were a mythical spur for a continuous effort, not for the civilization of the tropics, but for the cultivation of a "tropical civilization" - which might well define BM's original landscape architecture and general artistic sensitivity ${ }^{21}$.

\section{Bibliography}

ANGOTTI-SALGUeIRo, Heliana (Ed.) (2007). O Olho Fotográfico. Marcel Gautherot e seu tempo. São Paulo: FAAP

BANDEIRA, Júlio 1999. Debret e a Corte no Brasil. In Martins, Carlos (org.) O Brasil Redescoberto. Rio de Janeiro: Paço Imperial / BNDES

BLACKER, Mary Rose (2000). Flora Domestica. A History of Flower Arranging 1500-1930. London: The National Trust

BRUFORD, W. H. (1975). The German Tradition of Self-Cultivation. Bildung from Humboldt to Thomas Mann. Cambridge: Cambridge University Press. CALS, Soraia (1995). Roberto Burle Marx: uma Fotobiografia. Rio de Janeiro: S. Cals CUNHA, Euclydes da 1957 [1902] Rebellion in the Backlands, University of Chicago Press,

DEAN, Warren (1991). “A Botânica e a Politica Imperial: a introdução e a

\footnotetext{
20 A very broadly conceived exposition, under the curatorship of Lauro Cavalcanti, open during the first half of 2009: "Roberto Burle Marx 100 anos - A permanência do instável”.

21 In a sense not entirely distant from G. Freyre’s effort of interpreting Brazil.
} 
domesticação de plantas no Brasil.” Estudos Históricos 4-8.

DEL PRIORE, Mary (2008). Condessa de Barral: a paixão do Imperador. Rio de Janeiro, Objetiva.

DUARTE, Luiz F. D. (2005). La nature nationale: entre l'universalisme scientifique et la particularité symbolique des nations. Civilisations LII (2): 21-44.

DUARTE, Luiz F. D. (2007). The romantic drive and human sciences in Western culture, Revista Brasileira de Ciências Sociais, vol. 4 n. se (special edition). Digital version on-line: SciELO Social Sciences

ELLIOT, Brent (2003). Flora. An Illustrated History of the Garden Flower. London, Scriptum Editions / The Royal Horticultural Society.

FALCI, Miridan B.; MELO, HIldete P. Riqueza e emancipação: Eufrásia Teixeira Leite, uma análise de gênero. Estudos Históricos, 29 pp. 165-185

FREYRE, Gilberto 1946 [1933]. The Masters and the Slaves: A Study in the Development of Brazilian Civilization. New York : A. A. Knopf

GUÉRIOS, Paulo R. (2003). Heitor Villa-Lobos: o caminho sinuoso da predestinação. Rio de Janeiro, Editora FGV.

GUSDORF, Georges (1985). Le Savoir Romantique de la Nature. Paris, Payot.

ITAÚ CULTURAL (2009). Burle Marx. In Enciclopédia de Artes Visuais.

http://www.itaucultural.org.br/aplicexternas/enciclopedia_ic/index.

$\mathrm{cfm}$ ?fuseaction=artistas_biografia $\& \mathrm{~cd}$ _verbete $=667 \&$ lst_palavras $=\& \mathrm{~cd}$ _ idioma $=28555 \&$ cd_item $=1$. Access on July, 5th. 2009

LEENHARDT, Jacques (Ed.) (2006). Nos jardins de Burle Marx. Estudos 150. São Paulo, Perspectiva.

LÉVI-STRAUSS, Claude (1970). O pensamento selvagem. Rio de Janeiro: Companhia Editora Nacional.

LORENZI, Harri \& MELLO FILHO, Luiz E. de (2001). As plantas tropicais de R. Burle Marx. São Paulo: Instituto Plantarum de Estudos da Flora.

OlIVEIRA, Ana Rosa de (Ed.) (2007). Tantas vezes paisagem. Rio de Janeiro: Fundação Casa de Rui Barbosa / FAPERJ.

Pinheiro, Claudia \& Modesto, Cecília (Eds.) (2008). À Mesa, com Burle Marx. Brasília, D. F.: Batel.

REINHEIMER, Patricia (2008). A singularidade como regime de grandeza: nação e indivíduo como valores no discurso artístico brasileiro. Ph. D. Thesis, PPGAS/ Museu Nacional/Universidade Federal do Rio de Janeiro

SANTOS, Nubia M., Márcia P. CARVALHO, et al. (2002). Burle Marx.Jardins e Ecologia. Rio de Janeiro, Jauá Editora / SENAC Rio Editora. 
SCHAMA, Simon (1995). Paisagem e Memória. São Paulo: Companhia das Letras.

SCHNEIDER, Sylk (2007). Goethes Reise nach Brasilien. Die Gedankenreise eines Genies. Weimarer Taschenbuch Verlag. 192 p.

SCHWARCZ, Lilia M. (1998). As barbas do imperador: D. Pedro II, um monarca nos trópicos. São Paulo: Companhia das Letras.

SCHWARCZ, Lilia M. (2008). O Sol do Brasil. Nicolas-Antoine Taunay e as desventuras dos artistas franceses na corte de D. João. São Paulo: Companhia das Letras.

SEGALA, Lygia (2006). Perspective Observation and Illustration of Brazil: Victor Frond's (1857-1861) Photographic Project. Portuguese Studies, v. 22, p. 01-15 SIQUEIRA, Vera B. (2001). Burle Marx. São Paulo: Cosac \& Naify Edições TABACOW, José (Ed.) (2004). Arte \& Paisagem: (conferências escolhidas) / Roberto Burle Marx. São Paulo: Studio Nobel.

TAYLOR, Charles (1989). Sources of the Self. The Making of the Modern Identity. Cambridge, MA., Harvard University Press.

TERRA, Carlos G. (1993). Os jardins no Brasil do século XIX: Glaziou Revisitado. Rio de Janeiro: UFRJ / EBA.

VIEIRA, Maria Elena M. (2007). O jardim e a paisagem: espaço, arte, lugar. São Paulo: Annablume Editora.

WIKIPEDIA (2009). Burle Marx. http://en.wikipedia.org/wiki/Burle_Marx. Access on July 5th. 2009 